\title{
OPTIMUM POSITIONING OF SHEAR WALLS FOR MINIMIZING THE EFFECTS OF LATERAL FORCES IN MULTISTOREY-BUILDINGS
}

\begin{abstract}
A. TITIKSH ${ }^{1}$, G. BHATT ${ }^{2}$
Abstract: Shear walls are the most commonly used lateral load resisting systems in high rises. They have high plane stiffness and strength which can be used to simultaneously resist large horizontal loads while also supporting gravity loads. Hence it is necessary to determine effective and ideal locations of shear walls. Shear wall arrangement must be absolutely accurate, if not, it may cause negative effects instead. In this project, a study has been carried out to determine the effects of additions of shear walls and also the optimum structural configuration of multistory buildings by changing the shear wall locations radically. Four different cases of shear wall positions for $\mathrm{G}+10$ storey buildings have been analyzed by computer application software ETABS. The framed structure was subjected to lateral and gravity loading in accordance with the Indian Standards provision and the results were analyzed to determine the optimum positioning of the shear walls.
\end{abstract}

Keywords: Shear Wall, ETABS, Seismic Forces, RCC Structures, IS:1893-2002 (Part-1)

\section{INTRODUCTION}

Reinforced concrete (RC) buildings often have vertical plate-like RC walls called Shear Walls in addition to slabs, beams and columns. These walls generally start at foundation level and continue throughout the building's height. Their thickness can be as little as $150 \mathrm{~mm}$, or as much as $400 \mathrm{~mm}$ in high rise buildings. Shear walls are like vertically-oriented wide beams and are usually mounted along both the length and the width of buildings [1].

\footnotetext{
${ }^{1}$ Ph.D. Scholar, Department of Civil Engineering, National Institute of Technology, Raipur, India, e-mail: abhyuday2010@gmail.com

${ }^{2}$ Assistant Professor, Ph.D., Eng., Department of Civil Engineering, National Institute of Technology, Raipur, India, e-mail: gov.ce@nitrr.ac.in
} 
In India, reinforced concrete structures are designed and detailed per Indian Code IS:456-2002. However, structures located in high seismic regions require ductile design and detailing [3]. Provisions for ductile detailing of monolithic reinforced concrete frames and shear wall structures are specified in IS:13920-1993. After the 2001 Bhuj earthquake, this code has been made mandatory for all structures in zones III, IV, and V. Properly designed and detailed buildings with shear walls have shown very good performance in past earthquakes. [4] Shear walls provide large strength and stiffness to buildings in the direction of their orientation, which significantly reduces lateral sway of the building and thereby reduces damage to the structure and its contents. Shear walls in high seismic regions require special detailing. Shear walls are easy to construct, because reinforcement detailing of the walls is relatively straight-forward and therefore easily implemented on site. Shear walls are efficient, both in terms of construction cost and effectiveness in minimizing earthquake damage in structural and non-structural elements (like glass windows and building contents). Although the overall budget for the structure increases slightly, the enhanced structural efficiency balances out these costs.

\subsection{GEOMETRY \& DETAILING OF SHEAR WALLS}

Shear walls are oblong in cross-section, i.e., one dimension of the cross-sections is much larger than the other. While rectangular cross-sections are common, L- and U-shaped sections are also used. Thin-walled hollow RC shafts around the elevator cores of buildings also act as shear walls, and should be taken advantage of to resist earthquake forces [5]. Steel reinforcing bars are to be placed in walls in regularly spaced vertical and horizontal grids. The vertical and horizontal reinforcement in the wall can be placed in one or two parallel layers called curtains. Horizontal reinforcement needs to be anchored to the ends of the walls. The minimum area of reinforcing steel to be provided is 0.0025 times the cross-sectional area, along each of the horizontal and vertical directions [5]. This vertical reinforcement should be distributed uniformly across the wall cross-section. Under the large overturning effects caused by horizontal earthquake forces, edges of shear walls experience high compressive and tensile stresses. To ensure that shear walls behave in a ductile way, concrete in the wall end regions must be reinforced in a special manner to sustain these load reversals without losing strength [6]. End regions of walls with increased confinement are called Boundary elements. This special confining transverse reinforcement in boundary elements is similar to that provided in columns of RC frames. Sometimes, the thickness of the shear wall in these boundary elements is also increased. RC walls with boundary elements have substantially higher bending strength and 
horizontal shear force- carrying capacity, and are therefore less susceptible to earthquake damage than walls without boundary elements [7].
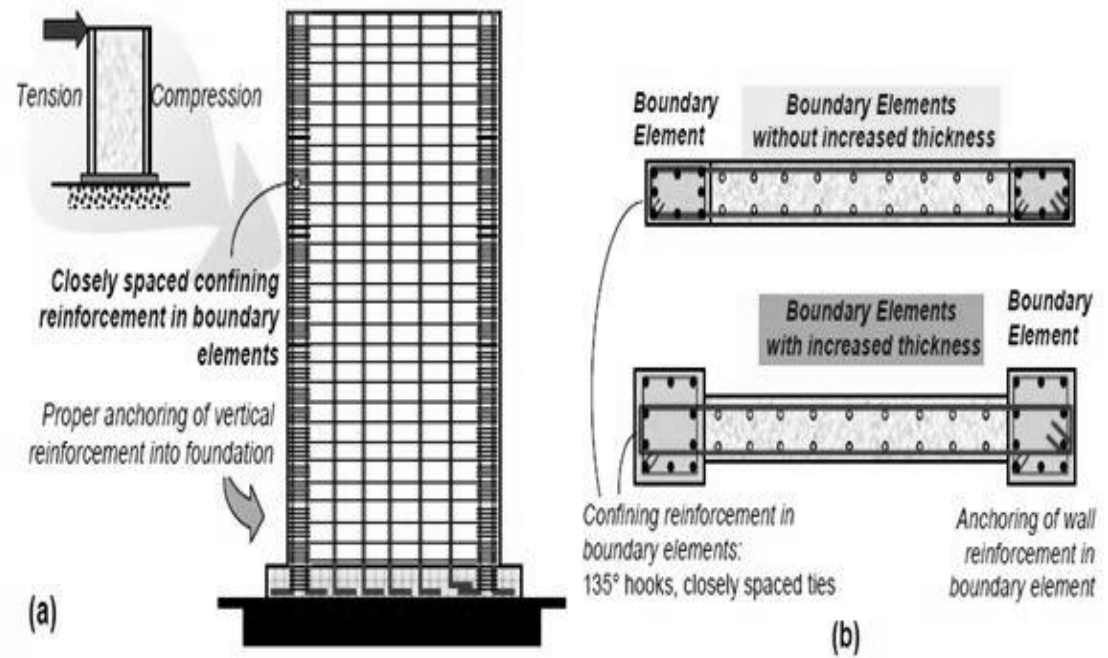

Fig. 1. Layout of Main Reinforcement in Shear Wall as per IS:13920:1993 (IITK: Earthquake Tips)

\section{MODELLING \& ANALYSIS IN ETABS}

The following assumptions were made before the start of the modeling procedure so as to maintain similar conditions for all four models:

- Only the main block of the building is considered. The staircases are not considered in the design procedure.

- The building is to be used for residential purposes, though no walls are installed as the study focuses only on the response of Frame configuration.

- On the ground floor, slabs are not installed and the plinth is resting $2 \mathrm{~m}$ above ground.

- The beams are resting centrally on the columns so as to avoid the conditions of eccentricity. This is achieved automatically in ETABS.

○ The footings are not designed. Supports are assigned in the form of fixed supports.

- Seismic loads are considered in the horizontal direction only (X \& Y) and the loads in the vertical direction $(Z)$ are assumed to be insignificant. 
Table 1. Model Descriptions

\begin{tabular}{|c|c|c|c|c|}
\hline SN & \multicolumn{3}{|c|}{ Specifications } & Size \\
\hline 1 & \multicolumn{3}{|c|}{ Plan dimensions } & $18 \mathrm{~m} \times 18 \mathrm{~m}\left(\mathrm{X}^{*} \mathrm{Y}\right)$ \\
\hline 2 & \multicolumn{3}{|c|}{ Length in $\mathrm{X}$ - direction } & $18 \mathrm{~m}$ (6 Bays) \\
\hline 3 & \multicolumn{3}{|c|}{ Length in Z- direction } & $18 \mathrm{~m}$ (6 Bays) \\
\hline 4 & \multicolumn{3}{|c|}{ Floor to floor height } & $3.0 \mathrm{~m}$ \\
\hline 5 & \multicolumn{3}{|c|}{ Plinth Level } & $2 \mathrm{~m}$ \\
\hline 6 & \multicolumn{3}{|c|}{ Total height of Building $(\mathrm{G}+10)$} & $35 \mathrm{~m}$ \\
\hline 7 & \multicolumn{3}{|c|}{ Slab Thickness } & $200 \mathrm{~mm}$ \\
\hline 8 & \multicolumn{3}{|c|}{ Type of Structure } & OMRF having Shear Walls \\
\hline 9 & \multicolumn{3}{|c|}{ Soil Type (as per IS:1893-2002) } & Medium \\
\hline 10 & \multicolumn{3}{|c|}{ Response Reduction Factor } & 5 \\
\hline 11 & \multicolumn{3}{|c|}{ Importance Factor } & 1 \\
\hline 12 & \multicolumn{3}{|c|}{ Seismic Zone Factor } & $0.36($ Zone $\mathrm{V})$ \\
\hline 13 & \multicolumn{3}{|c|}{ Time Factor } & 0.963 \\
\hline 14 & \multicolumn{3}{|c|}{ Grade of concrete } & M25 \\
\hline 15 & \multicolumn{3}{|c|}{ Grade of Steel } & Fe 415 \\
\hline 16 & \multicolumn{3}{|c|}{ Plinth Beam Size } & $0.23 \mathrm{~m} \times 0.23 \mathrm{~m}$ \\
\hline 17 & \multicolumn{3}{|c|}{ Floor Beam Size } & $0.23 \mathrm{~m} \mathrm{x} 0.48 \mathrm{~m}$ \\
\hline 18 & \multicolumn{3}{|c|}{ Column Size } & $0.30 \mathrm{~m} \times 0.70 \mathrm{~m}$ \\
\hline \multirow{4}{*}{19} & \multirow{4}{*}{$\begin{array}{l}\text { Loads } \\
\text { Applied }\end{array}$} & \multirow{2}{*}{ DL } & Dead Load & Calculated as per Self Weight \\
\hline & & & Floor Finish & $1 \mathrm{kN} / \mathrm{m}^{2}$ \\
\hline & & $\mathrm{LL}$ & Live Load & $2.5 \mathrm{kN} / \mathrm{m}^{2}$ \\
\hline & & EQX & Seismic Load (X direction) & Calculated as per IS:1893-2002 \\
\hline 20 & \multicolumn{3}{|c|}{ Load Combination } & $1.2 \mathrm{DL}+1.2 \mathrm{LL}+1.2 \mathrm{EQX}$ \\
\hline
\end{tabular}

Exact seismic analysis of the structure is highly complex and to tackle this complexity, much research has been done with the aim of countering the complex dynamic effects of seismic induced forces in structures, for the design of earthquake resistant structures in a refined and easy manner [8]. For this project, four models were made. Their descriptions are as follows:

\section{Case [1] Conventional Frame (Fig. 2)}

Case [2] Building with Shear Walls on Periphery at Corners (Fig. 3)

Case [3] Building with Shear Walls on Periphery at Centers (Fig. 4)

Case [4] Building with Box-type Shear Wall at the center of the geometry (Fig. 5) 


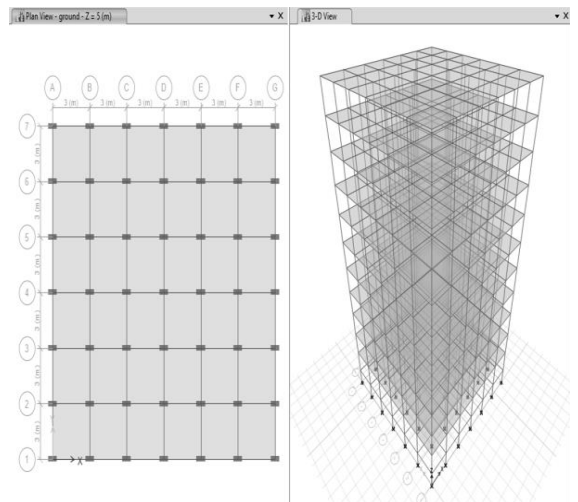

Fig. 2. Case [1]

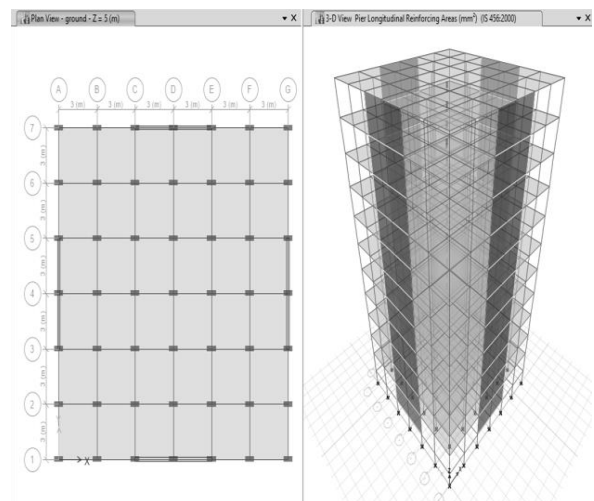

Fig. 4. Case [3]

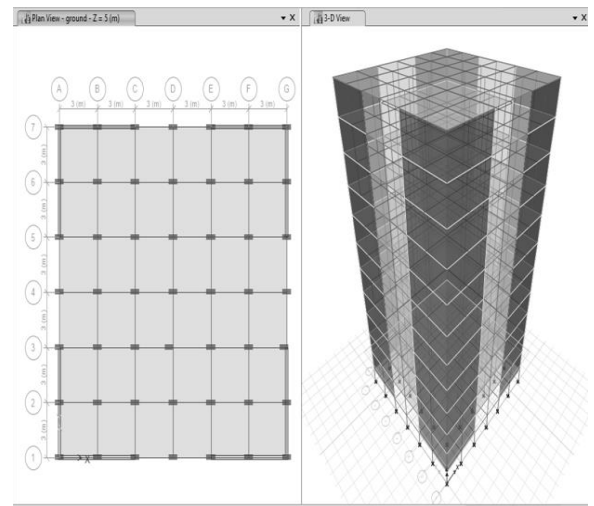

Fig. 3. Case [2]

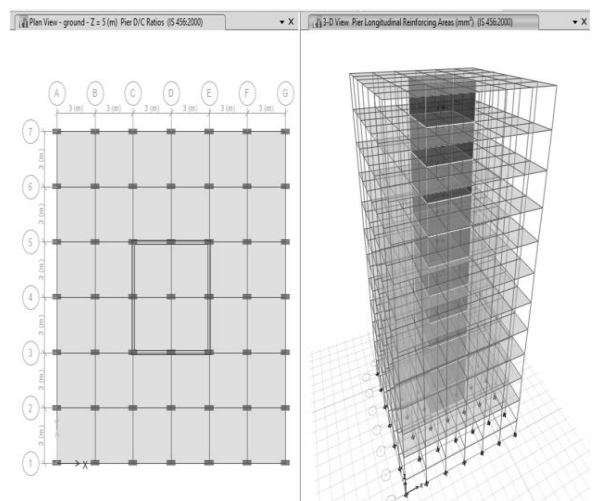

Fig. 5. Case [4]

The behavior of all the framing systems is taken as a basic study on the modeled structure. The lateral drift/deflection ratio is checked against the clause 7.11.1 of IS-1893:2002 (i.e. under transient seismic loads). The two parameters considered to present a comparison between the different frames are Maximum Storey Drift and Storey Shear. Many load combinations were considered during the analysis of the model, however for asserting the simplest yet most reliable method for analysis, the combined action of DL, LL \& EQ forces was considered (i.e. 1.2 DL + 1.2 $\mathrm{LL}+1.2 \mathrm{EQX})$. The structures with different framing system have been modeled using ETABS with the above mentioned load conditions and combinations. 


\section{RESULTS \& DISCUSSIONS}

1. Storey Drift-

Table 2. Values of Storey Drifts for different Cases

\begin{tabular}{|c|c|c|c|c|}
\hline Story Level & Case 1 & Case 2 & Case 3 & Case 4 \\
\hline 10 & 0.000403 & 0.000417 & 0.000491 & 0.000373 \\
\hline 9 & 0.000571 & 0.000427 & 0.000535 & 0.000403 \\
\hline 8 & 0.000737 & 0.000441 & 0.000570 & 0.000422 \\
\hline 7 & 0.000875 & 0.000452 & 0.000602 & 0.000437 \\
\hline 6 & 0.000982 & 0.000456 & 0.000624 & 0.000446 \\
\hline 5 & 0.001060 & 0.000452 & 0.000633 & 0.000447 \\
\hline 4 & 0.001113 & 0.000438 & 0.000625 & 0.000438 \\
\hline 3 & 0.001143 & 0.000414 & 0.000597 & 0.000419 \\
\hline 2 & 0.001155 & 0.000377 & 0.000547 & 0.000390 \\
\hline 1 & 0.001162 & 0.000342 & 0.000490 & 0.000371 \\
\hline Plinth & 0.001186 & 0.000414 & 0.000544 & 0.000453 \\
\hline Ground & 0.000607 & 0.000499 & 0.000564 & 0.000494 \\
\hline
\end{tabular}

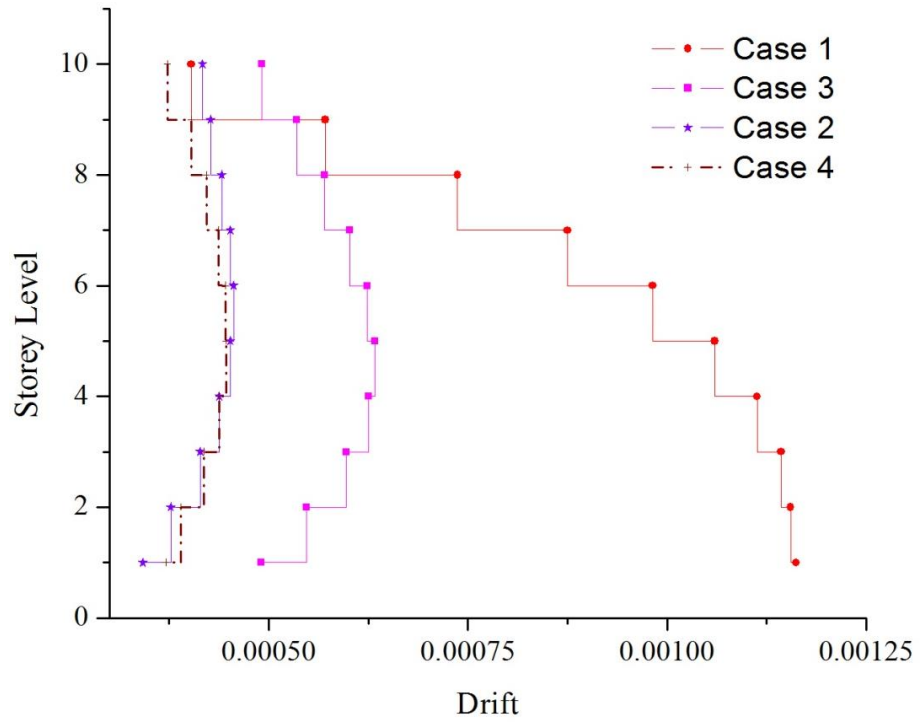

Fig. 6. Values of Storey Drifts for different Cases 


\section{Storey Shear (in kN) -}

Table 3. Values of Storey Shear for different Cases

\begin{tabular}{|c|c|c|c|c|}
\hline Story & Case 1 & Case 2 & Case 3 & Case 4 \\
\hline 10 & 510.3550 & 573.3626 & 490.0079 & 460.2861 \\
\hline 9 & 988.2740 & 1152.7917 & 975.2471 & 921.1207 \\
\hline 8 & 1380.7836 & 1628.6704 & 1373.7688 & 1299.5992 \\
\hline 7 & 1696.2848 & 2011.1841 & 1694.1024 & 1603.8221 \\
\hline 6 & 1943.1784 & 2311.1425 & 1944.7778 & 1841.8900 \\
\hline 5 & 2129.8655 & 2537.9542 & 2134.3243 & 2021.9036 \\
\hline 4 & 2264.7469 & 2701.4844 & 2271.2717 & 2151.9634 \\
\hline 3 & 2356.2236 & 2812.3908 & 2364.1495 & 2240.1700 \\
\hline 2 & 2412.6965 & 2880.8585 & 2421.4873 & 2294.6241 \\
\hline 1 & 2442.5664 & 2917.0728 & 2451.8148 & 2323.4263 \\
\hline Plinth & 2454.2343 & 2931.219 & 2463.6615 & 2334.6771 \\
\hline Ground & 2454.7366 & 2931.9153 & 2464.2006 & 2335.2795 \\
\hline
\end{tabular}

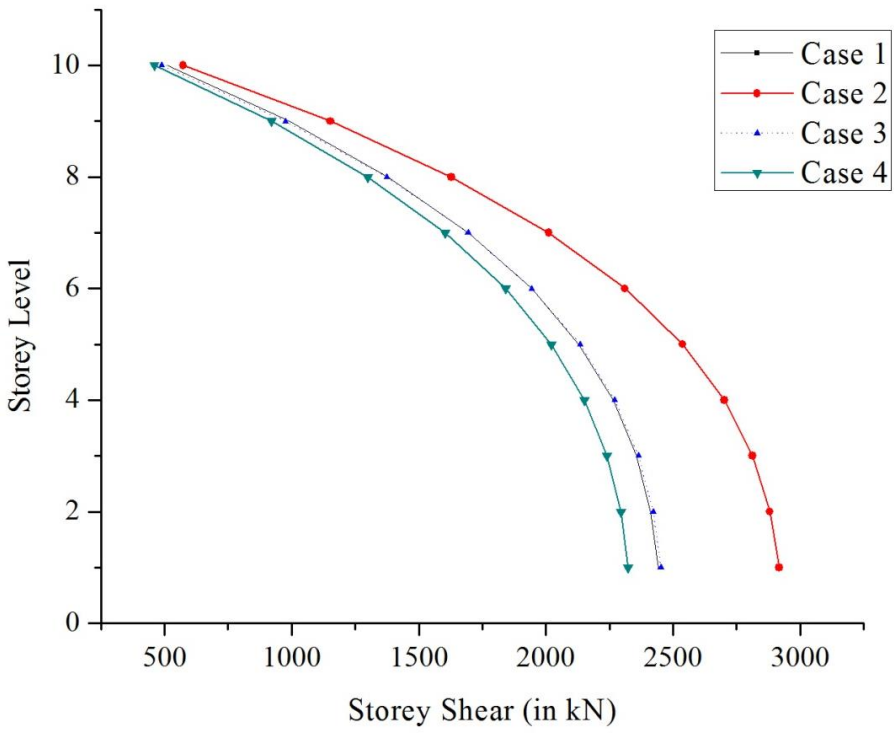

Fig. 7. Values of Storey Shear for different Cases 
It is clear that the seismic hazard has to be carefully evaluated before the construction of important high-rise structures. Based on the above analytical study carried out on 4 models, it is evident that buildings with shear walls behave more effectively than conventional frames when subjected to seismic loads. In all the systems, the Storey Drift is within the permissible limits as per Clause 7.11.1 of IS:1893-2002 (Part-1), which states that the storey drift in any storey due to the minimum specified design lateral force- (with partial load factor of 1.0), shall not exceed 0.004 times the storey height [9].

According to Clause 7.8.1 of IS:1893-2002 (Part-1), Dynamic analysis shall be performed to obtain the design seismic force, and its distribution to different levels along the height of the building and to the various lateral load resisting elements, for Regular buildings which are greater than $40 \mathrm{~m}$ in height in Zones IV and V, and those greater than $90 \mathrm{~m}$ in height in Zones II and I. Their Modelling is to be done as per 7.8.4.5 of IS:1893-2002 (Part-1). In this case dynamic analysis was not needed as the structure was only $35 \mathrm{~m}$ in height and placed in Zone V. With a drop in the seismic zone, the earthquake hazard will also increase. In such cases, the use of shear walls shall become mandatory for achieving safety in design. These walls are designed according to the provisions and specifications laid down in IS:456-2000 [10]. It is clear from the results that the frame with Shear Walls provides more safety for the designers and although it proves to be a little costly, it is also extremely effective in terms of structural stability.

\section{SUMMARY \& CONCLUSIONS}

In terms of the Storey Drift, it was CASE 4- (closely followed by CASE 2), which showed better results when compared to other models. This leads us to believe that when Shear Walls are placed at the center of the geometry in the form of a box or at the corners, the structures behave in a more stable manner. This practice of providing Box-type Shear Walls is becoming more popular now-adays as high rise structures generally have a lift system. These box-type shear walls serve the dual purpose of Shear walls as well as vertical ducts or passages for the movement of lifts. The main difference in the behaviors of CASE 4 and CASE 2 can be noticed when comparing the Storey Shear. CASE 2 displayed much higher values of storey shear as compared to the other models. Here CASE 4 proved to be the best. It is therefore safe to conclude that among all other considered possibilities, CASE 4 (Building with Box-type Shear Wall at the center of the geometry) is the ideal framing technique for medium \& high rise buildings. To further increase the effectiveness of the structure, earthquake resisting techniques such as Seismic Dampers \& Base Isolation can be used. 


\section{LIMITATIONS \& SCOPE FOR FUTURE WORK}

This study is limited to the optimum positioning of shear walls in high rises but it does not consider the effects of curtailment of shear walls on the lateral load- resisting capacity of buildings. Further analysis needs to be carried out on the Box type- shear wall configuration by curtailing the shear walls on or near the top floor as a majority of the loads are acting near the ground. Also, the design results can be verified according to international codes such as Eurocode EC8 to prepare a comparative chart with respect to the provisions laid down in Indian code IS:1893-2002 (Part-1).

\section{REFERENCES}

1. S. Anshumn, D. Bhunia, B. Rmjiyani, "Solution of shear wall location in Multi-storey building”, International Journal of Civil Engineering 9 (2): 493-506, 2011.

2. M. Asharaf, Z.A. Siddiqi, M.A. Javed, "Configuration of Multi-storey building subjected to lateral forces", Asian Journal of Civil Engineering (Building \& Housing) 9 (5): 525-537, 2015.

3. H.S. Kim, D.G. Lee, “Analysis of shear wall with openings using super elements”, Engineering Structures 25: 981-991, 2003.

4. M. Shariq, H. Abbas, H. Irtaza, M. Qamaruddin, "Influence of openings on seismic performance of masonry building walls", Building and Environment 43: 1232-1240, 2008.

5. C.V.R. Murthy, "Earthquake Tips", National Information Center of Earthquake Engineering, Indian Institute of Technology Kanpur, India, 2005.

6. S.A. Meftah, A. Tounsi, A.B. El-Abbas, "A simplified approach for seismic calculation of a tall building braced by shear walls and thin-walled open section structures", Engineering Structures 29: 2576-2585, 2007.

7. Q. Wang, L. Wang, Q. Liu, "Effect of shear wall height on earthquake response", Engineering Structures 23: 376-384, 2001.

8. S.K. Duggal, "Earthquake Resistant Design Structures", Oxford University Press, New Delhi, 2010.

9. Bureau of Indian Standards. IS:1893-2002 (Part-1) Criteria for earthquake Resistant Design of Structures. New Delhi, India.

10. Bureau of Indian Standards. IS:456-2000 Plain and Reinforced Concrete Code of Practice. New Delhi, India. 


\section{LIST OF FIGURES AND TABLES:}

Fig. 1. Layout of Main Reinforcement in Shear Wall as per IS:13920:1993 (IITK: Earthquake Tips)

Rys. 1. Układ głównego zbrojenia w ścianie oporowej, zgodnie z IS:13920:1993 (IITK: Porady dotyczące trzęsienia ziemi).

Fig. 2. CASE [1]

Rys. 2. PRZYPADEK [1].

Fig. 3. CASE [2]

Rys. 3. PRZYPADEK [2].

Fig. 4. CASE [3]

Rys. 4. PRZYPADEK [3].

Fig. 5. CASE [4]

Rys. 5. PRZYPADEK [4].

Fig. 6. Values of Storey Drifts for different Cases

Rys. 6. Wartości Dryftowań Kondygnacji w różnych przypadkach.

Fig. 7. Values of Storey Shear for different Cases

Rys. 7. Wartości Oporu Kondygnacji w różnych przypadkach.

Tab. 1. Model Descriptions

Tab. 1. Opisy modeli.

Tab. 2. Values of Storey Drifts for different Cases

Tab. 2 Wartośći Dryftowań Kondygnacji w różnych przypadkach.

Tab. 3. Values of Storey Shear for different Cases

Tab. 3 Wartości Oporu Kondygnacji w różnych przypadkach. 


\title{
OPTYMALNE POLOŻENIE ŚCIAN OPOROWYCH MAJĄCE NA CELU ZMINIMALIZOWANIE SKUTKÓW BOCZNYCH SIL W WIELOPOZIOMOWYCH BUDYNKACH
}

\author{
Slowa kluczowe: Ściana oporowa, siły sejsmiczne, konstrukcje RCC, IS:1893-2002 (Część-1)
}

\section{STRESZCZENIE:}

Ściany oporowe są prawdopodobnie jednym z najczęściej stosowanych systemów bocznego obciążenia w średnich i wysokich budynkach. Charakteryzują się one wysoką sztywnością płaszczyzny oraz wytrzymałością. Mogą one wytrzymać duże poziome obciążenia oraz obciążenie grawitacyjne. Zastosowanie ścian oporowych staje się obecnie nieuniknione w przypadku konstrukcji wielokondygnacyjnych. Stąd też bardzo istotne jest określenie skutecznego, efektywnego i idealnego położenia ściany oporowej w budynkach. Układ ściany oporowej musi być bardzo dokładny, bo jeśli nie, może powodować negatywne skutki. Prawidłowo zaprojektowane budynki ze ścianami oporowymi dały bardzo dobre wyniki podczas ostatnich trzęsień ziemi. Ściany oporowe gwarantują dużą wytrzymałość i sztywność budynków, zgodnie z kierunkiem ich orientacji, co znacznie zmniejsza boczne kołysanie budynku, a tym samym ogranicza możliwość uszkodzenia konstrukcji i jej zawartości. Ściany oporowe w regionach o wysokiej aktywności sejsmicznej wymagają specjalnych detali. Przepisy dotyczące detali monolitycznych konstrukcji żelbetowych i konstrukcji ze ścian oporowych zostały opisane w IS 13920 (1993). Po trzęsieniu ziemi w Bhuj, które miało miejsce w 2001 roku, kodeks ten stał się obowiązkowy dla wszystkich konstrukcji w strefach III, IV i V.

W niniejszym projekcie przeprowadzono badanie mające na celu określenie wpływu dodatkowych ścian oporowych, a także optymalnej konfiguracji strukturalnej budynku wielopiętrowego, w drodze radykalnej zmiany położenia ściany oporowej. Rozpatrzono cztery różne przypadki położenia ściany oporowej dla budynków o kondygnacjach $\mathrm{G}+10$, przy zachowaniu zerowej ekscentryczności między środkiem masy i środkiem sztywności. Są to:

- $\quad$ PRZYPADEK [1]: Konwencjonalne ramy bez ścian oporowych

- $\quad$ PRZYPADEK [2]: Budynki ze ścianami oporowymi na obrzeżach

- PRZYPADEK [3]: Budynki ze ścianami oporowymi na obrzeżach przy środkowej części

- $\quad$ PRZYPADEK [4]: Budynki ze ścianami oporowymi o konstrukcji skrzynkowej w środku geometrii

Modelowanie powyższych czterech modeli zostało wykonane przy użyciu oprogramowania komputerowego ATABS 2015. Powyższym modelom przypisano wymiary 18 x $18 \mathrm{~m}$ dla płaszczyzny z sześcioma osiami w obu kierunkach, całkowitą wysokość $35 \mathrm{~m} \mathrm{z}$ cokołem na wysokości $2 \mathrm{~m}$, oraz wysokość ściany wynoszącą $3 \mathrm{~m}$. Modele zostały wyposażone w elewacje ram odpornych na zginanie (OMRF) wraz z konfiguracją ściany oporowej. Zgodnie z IS:18932002 (Część-1), przyjęty został średni rodzaj gleby, Współczynnik Redukcji R otrzymał wartość 5, Współczynnik Ważności I wartość 1.0. Modele zostały umieszczone w strefie sejsmicznej V, dla której czynnik strefy Z wynosi 0.36 . W przypadku całej geometrii, w niniejszym badaniu zastosowano wartość M25 i Fe415. Zastosowano przekroje belek cokołowych o wymiarach $0.23 \mathrm{~m}$ x $0.23 \mathrm{~m}$ oraz belek podłogowych o wymiarach $0.23 \mathrm{~m}$ x $0.48 \mathrm{~m}$, a wymiary kolumny wyniosły $0.30 \mathrm{~m}$ x $0.70 \mathrm{~m}$. Konstrukcja szkieletowa została poddana bocznemu i grawitacyjnemu obciążeniu, zgodnie z przepisami IS, a wyniki zostały poddane analizie, w celu określenia optymalnego położenia ściany oporowej. W celu opracowania najprostszej, a jednocześnie najbardziej wiarygodnej metody analizy, rozważono połączone działanie 
Ciężaru Własnego, Ciężaru Użytkowego oraz Sił Sejsmicznych w kierunku poziomym (tj. 1.2 DL + 1.2 LL + 1.2 EQZ). Zachowanie wszystkich systemów szkieletowych zostało potraktowane jako podstawowe badanie modelowanej konstrukcji. Poprzeczny współczynnik dryfowania/ ugięcia został sprawdzony zgodnie z klauzulą 7.11.1 w ramach IS1893:2002 (tj. pod przejściowymi obciążeniami sejsmicznymi). Te dwa parametry, uznane za przedstawiające porównanie między poszczególnymi ramami, stanowią maksymalne obciążenie kondygnacji. Przeprowadzono również ręczne kontrole zgodnie z IS:1893-2002 (Część-2) i IS:3920-993, w celu sprawdzenia ważności wyników.

Pod względem Dryfowania Kondygnacji, PRZYPADEK 4, bardzo zbliżony do PRZYPADKU 2, dał lepsze wyniki w porównaniu do innych modeli. Pozwoliło nam to przypuszczać, że gdy Ściany Oporowe znajdują się w środku geometrii i przyjmują postać skrzynkową lub są umieszczone w narożnikach, wówczas konstrukcje zachowują się w bardziej stabilny sposób. Ta praktyka stosowania Ścian Oporowych o Konstrukcji Skrzynkowej staje się coraz bardziej popularna, ponieważ wysokie konstrukcje są zazwyczaj wyposażone w system podnoszenia kontrolnego, a ściany oporowe o konstrukcji skrzynkowej służą podwójnemu celowi - jako ściany oporowe oraz pionowy kanu lub przejście dla ruchu wind. Główną różnicę w zachowaniach z PRZYPADKU 4 i PRZYPADKU 2 można zauważyć podczas porównywania Oporu Kondygnacji. PRZYPADEK 2 przedstawia dużo wyższe wartości oporu kondygnacj, w porównaniu do innych modeli. W tej sytuacji, PRZYPADEK 4 okazał się najlepszy.

Na podstawie niniejszego badania można zatem bezpiecznie stwierdzić, że ściany oporowe o konstrukcji skrzynkowej umieszczone w środku geometrii budynku dają najlepsze wyniki. Aby jeszcze bardziej zwiększyć efektywność konstrukcji, możliwe jest zastosowanie technik odporności na trzęsienie ziemi, takich jak Tłumiki Sejsmiczne czy Izolacja Podłoża. 